\title{
Overexpression of the Epidermal Growth Factor Receptor in Human Pancreatic Cancer Is Associated with Concomitant Increases in the Levels of Epidermal Growth Factor and Transforming Growth Factor Alpha
}

\author{
Murray Korc, * Bysani Chandrasekar, * Yoichiro Yamanaka, * Helmut Friess, Markus Buchler, and Hans G. Beger \\ *Division of Endocrinology and Metabolism, Departments of Medicine and Biological Chemistry, University of California, Irvine, \\ California 92717; and Department of Surgery, University of Ulm, D-7900 Ulm, Germany
}

\begin{abstract}
The epidermal growth factor (EGF) receptor is activated by both EGF and transforming growth factor-alpha (TGF- $\alpha$ ). Using immunohistochemical and immunoblotting techniques we now report that the EGF receptor, EGF, and TGF- $\alpha$ are found in both pancreatic acini and ducts in the normal human pancreas, and that all three proteins are expressed at higher levels in human pancreatic cancer tissues. Using in situ hybridization techniques, we also report that the mRNA encoding the EGF receptor, EGF, and TGF- $\alpha$ colocalize with their respective proteins. Northern blot analysis of total RNA indicates that, by comparison with the normal pancreas, the pancreatic tumors exhibit a 3-, 15-, and 10-fold increase in the mRNA levels encoding the EGF receptor, EGF, and TGF- $\alpha$, respectively. Furthermore, by in situ hybridization, there is a marked increase in these mRNA moieties within the tumor mass. These findings suggest that EGF and TGF- $\alpha$ may participate in the regulation of normal pancreatic exocrine function, and that overexpression of the EGF receptor and its two principal ligands may contribute to the pathophysiological processes that occur in human pancreatic cancer. (J. Clin. Invest. 1992. 90:13521360.) Key words: Northern blots • immunofluorescence • in situ hybridization $\bullet$ autocrine $\bullet$ pancreas
\end{abstract}

\section{Introduction}

Carcinoma of the pancreas is the fourth or fifth leading cause of cancer death in the United States (1). The one-year overall survival rate in patients with pancreatic carcinoma is only $12 \%$, and more than $98 \%$ of the patients are dead within five years (2). The diagnosis of pancreatic cancer is frequently established at an advanced stage, which precludes the patients from having surgery. Moreover, during surgical exploration of patients who ostensibly have localized disease, as many as $50 \%$ of the pancreatic carcinomas are found to have already spread locally or regionally (3). Nonsurgical treatment modalities for pancreatic cancer have not been successful, partly because of

Data from parts of this paper were presented at the American Gastroenterology Association Meeting, 19-22 May 1991, and the Keystone Symposia, 26 January to 2 February 1992.

Address correspondence to Dr. Murray Korc, Division of Endocrinology and Metabolism, Medical Sciences I, C240, University of California, Irvine, CA 92717.

Received for publication 11 February 1992 and in revised form 29 April 1992.

J. Clin. Invest.

(c) The American Society for Clinical Investigation, Inc.

0021-9738/92/10/1352/09 \$2.00

Volume 90, October 1992, 1352-1360 the tumor's propensity to metastasize and the intrinsic resistance of pancreatic cancer cells to cytotoxic agents (3).

The reasons for the aggressiveness of this disorder are not known. However, cultured human pancreatic carcinoma cells have an overabundance of epidermal growth factor (EGF) ${ }^{1}$ receptors, express transforming growth factor-alpha (TGF- $\alpha$ ), and avidly internalize and recycle EGF (4-6). Overexpression of the EGF receptor, a transmembrane protein which possesses intrinsic tyrosine kinase activity, is associated with the malignant phenotype (7-8) and with enhanced ability of certain tumors to invade normal tissues and to metastasize (9-10). Overexpression of either EGF or TGF- $\alpha$, both of which activate the EGF receptor, also leads to abnormal cell growth and acquisition of features that are characteristic of the transformed phenotype (11-12). Taken together, these observations raise the possibility that the abundance of EGF receptors and the concomitant availability of both EGF and TGF- $\alpha$ may provide human pancreatic cancer cells with a considerable growth advantage. However, the distribution of EGF and TGF- $\alpha$ in relation to the localization of the EGF receptor in normal and cancerous pancreatic tissues, and their exact site of synthesis within the human pancreas have not been investigated.

We now report that the EGF receptor, EGF, and TGF- $\alpha$ are expressed in the normal human pancreas, that these proteins and their respective mRNAs colocalize in the acinar cells and duct cells, and that all three proteins are overexpressed in pancreatic tumors by comparison with normal human pancreatic tissues.

\section{Methods}

Tissue samples. Normal human pancreatic tissue samples were obtained from 20 individuals through an organ donor program, and malignant pancreatic tissue samples were obtained from 12 female and 10 male patients during surgery for pancreatic cancer. The age of the cancer patients was 59 $\pm 2.3 \mathrm{yr}$ (mean $\pm \mathrm{SE}$ ), with a range of 23-69 yr. Histologically, there were four grade 1, thirteen grade 2, four grade 3, and one grade 4 duct cell adenocarcinomas. Most freshly removed tissue samples were fixed overnight in Bouin's solution, consisting of a 3 to 1 ratio of picric acid and formaldehyde. Some tissue samples were fixed overnight in 4\% paraformaldehyde, which was prepared with 100 $\mathrm{mM} \mathrm{NaPO}_{4}, \mathrm{pH}$ 7.4. Fixed tissues were paraffin embedded for histological analysis. Tissues destined for RNA extraction were frozen in liquid nitrogen immediately upon surgical removal, and maintained at $-80^{\circ} \mathrm{C}$ until use. All studies were approved by the Human Subjects Committees of the University of California, Irvine, and the University of Ulm, Germany.

Antibodies. All three primary antibodies were monoclonal and

1. Abbreviations used in this paper: EGF, epidermal growth factor; TGF- $\alpha$, transforming growth factor-alpha. 
were raised against human antigens. Anti-EGF receptor antibodies were purchased from Sigma Chemical Co. (St. Louis, MO), anti-EGF antibodies from Amgen, Inc. (Thousand Oaks, CA), and anti-TGF- $\alpha$ antibodies from Oncogene Sciences, Inc. (Manhasset, NY). Specificity of anti-EGF receptor antibodies was verified by preincubation for $6 \mathrm{~h}$ at $23^{\circ} \mathrm{C}$ with $\mathrm{A} 431$ cells, which resulted in complete loss of signal. Specificities of anti-EGF and anti-TGF- $\alpha$ antibodies were verified by preincubation for $1 \mathrm{~h}$ at $37^{\circ} \mathrm{C}$ and $14 \mathrm{~h}$ at $4^{\circ} \mathrm{C}$ with recombinant human EGF (rH-EGF, a gift from Dr. C. George-Nascimento at Chiron, Inc., Emeryville, CA), and recombinant human TGF- $\alpha$ (rH-TGF- $\alpha$, a gift from Dr. M. Winkler at Genentech, Inc., South San Francisco, CA), respectively. The signal obtained with anti-EGF antibodies was abolished by preincubation with EGF but not with TGF- $\alpha$, whereas the signal obtained with anti-TGF- $\alpha$ antibodies was abolished by incubating antibodies with TGF- $\alpha$ but not with EGF.

Immunocytochemistry. Serial paraffin-embedded sections $(5 \mu \mathrm{m}$ thick) were subjected to immunostaining, using an avidin-biotinylated immunoperoxidase technique (ABC kit; Oncogene Sciences, Inc., Manhasset, NY). After deparaffinization, endogenous peroxidase activity was blocked by incubating for $30 \mathrm{~min}$ at $23^{\circ} \mathrm{C}$ with $0.03 \%$ hydrogen peroxide in methanol. The sections were then incubated for $20 \mathrm{~min}$ at $23^{\circ} \mathrm{C}$ with $10 \%$ normal horse serum before overnight incubation at $4^{\circ} \mathrm{C}$ with the respective primary antibody diluted in PBS. Optimal results were obtained with the following antibody dilutions: EGFR, 1:400; EGF, 1:200; TGF- $\alpha, 1: 50$. Bound antibody was detected with a biotinylated anti-mouse IgG secondary antibody and avidin-biotin complex linked to horseradish peroxidase, followed by incubation with diaminobenzidine tetrahydrochloride as the substrate. Counterstaining was then performed with Mayer's hematoxylin.

Immunofluorescence microscopy. After deparaffinization, the tissue sections were washed in PBS containing $0.1 \%$ BSA, and then incubated for $60 \mathrm{~min}$ at $23^{\circ} \mathrm{C}$ with the respective primary antibody diluted in PBS containing $0.1 \%$ BSA. Optimal results were obtained with the following antibody dilutions: EGFR, 1:100; EGF, 1:20; TGF- $\alpha, 1: 20$. After washing to remove unbound antibody, the sections were incubated for $40 \mathrm{~min}$ at $23^{\circ} \mathrm{C}$ with a 1:20 dilution of FITC-labeled goat anti-mouse IgG, and washed with PBS. The coverslips were then mounted on glass slides in Citifluor (Ted Pella, Inc., Redding, CA ) and viewed with a Nikon Optiphot epifluorescence microscope with B filter composition.

Cell culture. A431 human vulvar carcinoma cells (13) were grown in 1:1 (vol/vol) DMEM/Ham's F-12 medium. Cells were propagated in monolayer culture at $37^{\circ} \mathrm{C}$ in a $5 \% \mathrm{CO}_{2} / 95 \%$ air atmosphere in media that were supplemented with $10 \% \mathrm{FCS}, 100 \mathrm{U} / \mathrm{ml}$ penicillin, and $100 \mu \mathrm{g} / \mathrm{ml}$ streptomycin.

Immunoblotting. Pancreatic homogenates from three normal organ donors and three patients with pancreatic cancer were subjected to 7.5\% SDS-PAGE for EGF receptor immunoblotting $(14,15)$ and tricine-16.5\% SDS-PAGE for EGF and TGF- $\alpha$ immunoblotting (16). After electrophoresis, proteins were transferred to nitrocellulose filters (17), blocked with $10 \%$ normal goat serum, and incubated for $18 \mathrm{~h}$ at $4^{\circ} \mathrm{C}$ with the respective primary antibodies (EGFR, 1:400; EGF, 1:200; TGF- $\alpha, 1: 10$ ). The filters were washed with a buffer containing $20 \mathrm{mM}$ Tris ( $\mathrm{pH} 7.5$ ), $500 \mathrm{mM} \mathrm{NaCl}$, and $0.05 \% \mathrm{vol} / \mathrm{vol}$ Tween-20, incubated for $2 \mathrm{~h}$ with goat anti-mouse IgG (1:2,500 dilution), and for $2 \mathrm{~h}$ with ${ }^{125} \mathrm{I}$-protein $\mathrm{A}(0.33 \mu \mathrm{Ci} / \mathrm{ml})$. After extensive washing with the Tweenbased buffer, the blots were exposed for $48-72 \mathrm{~h}$ at $-80^{\circ} \mathrm{C}$ to XAR-5 film (Kodak), using intensifying screens. The intensity of the radiographic bands was quantitated by laser densitometry.

Northern blot analysis. Total RNA was extracted by the guanidine isothiocyanate method, fractionated on $0.8 \%$ agarose $/ 2.2 \mathrm{M}$ formaldehyde gel, stained with ethidium bromide for verification of RNA integrity and loading equivalency, blot-transferred onto Nytran membranes (Schleicher \& Schuell, Keene, NH), and cross-linked by ultraviolet irradiation (18). The blots were then prehybridized, hybridized, and washed under two high stringency conditions, depending on whether antisense riboprobes or cDNA probes were used, as previously described (18-20). In the case of antisense riboprobes, the blots were prehybridized for $4 \mathrm{~h}$ at $65^{\circ} \mathrm{C}$ in $50 \%$ formamide, $0.5 \% \mathrm{SDS}, 5 \times$ standard saline citrate $(\mathrm{SSC})(1 \times \mathrm{SSC}=150 \mathrm{mM} \mathrm{NaCl}, 15 \mathrm{mM}$ Na citrate, pH 7.0), $5 \times$ Denhardt's $(1 \times$ Denhardt's $=0.02 \%$ Ficoll, $0.02 \%$ polyvinylpyrrolidone, and $0.02 \% \mathrm{BSA}), 250 \mu \mathrm{g} / \mathrm{ml}$ salmon sperm DNA, and $50 \mathrm{mM} \mathrm{Na}_{2} \mathrm{PO}_{4}, \mathrm{pH} 6.5(18)$. The blots were then hybridized for $16 \mathrm{~h}$ at $65^{\circ} \mathrm{C}$ in the presence of $5 \times 10^{5} \mathrm{cpm} / \mathrm{ml}$ of the labeled probe, washed at $65^{\circ} \mathrm{C}$ in a solution containing $1 \times$ sodium chloride sodium phosphate EDTA buffer (SSPE) ( $150 \mathrm{mM} \mathrm{NaCl}, 10 \mathrm{mM} \mathrm{NaH}_{2} \mathrm{PO}_{4}$, and $1 \mathrm{mM}$ EDTA), and $0.5 \%$ SDS, and twice at $68^{\circ} \mathrm{C}$ in a solution containing $0.1 \times$ SSPE and $0.5 \%$ SDS $(18)$. In the case of cDNA probes, blots were prehybridized for $1 \mathrm{~h}$ at $42^{\circ} \mathrm{C}$ in a prehybridization buffer that contained $50 \%$ formamide, $0.1 \%$ SDS, $5 \times$ SSC, $2.5 \times$ Denhardt's, $250 \mu \mathrm{g} / \mathrm{ml}$ salmon sperm DNA, $50 \mathrm{mM} \mathrm{Na} \mathrm{PO}_{4}, \mathrm{pH}$ 6.5. The blots were hybridized at $42^{\circ} \mathrm{C}$ for $16 \mathrm{~h}$ with the labeled cDNA probe $\left(6 \times 10^{4}\right.$ $\mathrm{cpm} / \mathrm{ml}$ ), washed twice at $23^{\circ} \mathrm{C}$ in $6 \times \mathrm{SSPE} / 0.5 \%$ SDS, twice at $37^{\circ} \mathrm{C}$ in $1 \times \mathrm{SSPE} / 0.5 \% \mathrm{SDS}$, and once at $57^{\circ} \mathrm{C}$ in $0.1 \times \mathrm{SSPE} / 0.5 \%$ SDS (18). All blots were exposed at $-80^{\circ} \mathrm{C}$ to Kodak XAR-5 film with Kodak intensifying screens, and the intensity of the radiographic bands was quantified by laser densitometry.

Two cDNA probes were used for filter hybridizations: a $0.56-\mathrm{kb}$ EcoRI fragment of human EGF phEGF121 cDNA (American Type Culture Collection, Rockville, MD), and a BamHI 0.19-kb fragment of the mouse $7 \mathrm{~S}$ ribosomal cDNA (21) that cross-hybridizes with human ribosomal RNA. In addition, a 0.86-kb EcoRI fragment of human EGF receptor HER pA21 cDNA and a 1.3-kb EcoRI fragment of human TGF- $\alpha$ cDNA were subcloned into the pGem 3 plasmid vector (22) before use in filter hybridizations. cDNA probes were labeled with [ $\alpha$ ${ }^{32} \mathrm{P}$ ]dCTP (3,000 Ci/mmol; New England Nuclear, Boston, MA) to a $\mathrm{sp}$ act of $0.5-1 \times 10^{9} \mathrm{dpm} / \mu \mathrm{g}$, using random hexanucleotide primers (23). The synthesis of antisense probes was carried out with $\left[{ }^{32} \mathrm{P}\right] \mathrm{CTP}$ $(3,000 \mathrm{Ci} / \mathrm{mmol}$, New England Nuclear $)$, yielding probes with a sp act of $0.8-1 \times 10^{9} \mathrm{cpm} / \mu \mathrm{g}(24)$.

In situ hybridization. Tissue sections were deparaffinized, incubated at $23^{\circ} \mathrm{C}$ for $10 \mathrm{~min}$ with $1 \mu \mathrm{g} / \mathrm{ml}$ proteinase $\mathrm{K}$ (Boehringer Mannheim Biochemicals, Indianapolis, IN), and for $10 \mathrm{~min}$ with $0.5 \times$ SSC. Tissue sections were then incubated for $3 \mathrm{~h}$ at $42^{\circ} \mathrm{C}$ in hybridization solution which contained $0.3 \mathrm{M} \mathrm{NaCl}, 20 \mathrm{mM}$ Tris, $\mathrm{pH} 8.0,5 \mathrm{mM}$ EDTA, $50 \%$ formamide, $1 \times$ Denhardt's, $10 \%$ dextran sulfate, and 10 $\mathrm{mM}$ dithiothreitol (25). Hybridization was initiated by the addition of fresh hybridization buffer containing $120,000 \mathrm{cpm}$ of the probe and 50 $\mu \mathrm{g}$ of yeast tRNA (Gibco BRL, Inc., Gaithersburg, MD), and continued overnight at $50^{\circ} \mathrm{C}(25)$. The sections were then washed at $23^{\circ} \mathrm{C}$ in $2 \times \mathrm{SSC}, 10 \mathrm{mM} \beta$-mercaptoethanol, and $1 \mathrm{mM}$ EDTA for $10 \mathrm{~min}$ (two times each), and digested with RNAse A ( $20 \mu \mathrm{g} / \mathrm{ml}$; Sigma Chemical Co., St. Louis, MO) for $30 \mathrm{~min}$ at $23^{\circ} \mathrm{C}$. The slides were then washed three times $(8 \mathrm{~min}$ each $)$ at $23^{\circ} \mathrm{C}$, and twice at $50^{\circ} \mathrm{C}(60 \mathrm{~min}$ each $)$ in $0.1 \times$ SSC, $10 \mathrm{mM} \beta$-mercaptoethanol, and $1 \mathrm{mM}$ EDTA (25). The sections were then washed twice ( $10 \mathrm{~min}$ each) in $0.5 \times \mathrm{SSC}$ at $23^{\circ} \mathrm{C}$, dehydrated by immersion in graded alcohol containing $0.3 \mathrm{M}$ ammonium acetate, dried, coated with NTB2 nuclear emulsion (Eastman Kodak Co.), and exposed in the dark for 5-10 d. After development the slides were counterstained with Mayer's hematoxylin.

The EGF receptor and TGF- $\alpha$ antisense probes described above were also used for in situ hybridization studies. In addition, a 0.56-kb EcoRI fragment of human EGF cDNA (26) was subcloned into the pSP65 plasmid vector, and used for synthesis of EGF antisense probe. Pretreatment of the slides with RNAse abolished the hybridization signal by the three antisense probes. Furthermore, sense probes corresponding to the three antisense probes failed to produce a signal.

Video image analysis. To obtain quantitative analysis of in situ hybridization data, sections were examined with a dark-field filter using a Nikon Diaphot microscope and Nikon FX microscopic photometric system (Tokyo, Japan) equipped with a video camera and a video image analysis system (Image I Videoimage Analysis System, West Chester, PA). Images were scanned for average pixel intensity and background density, allowing for computer-based correction of any uneven image illumination, using a Compaq computer and the Phoscan program (27). Densitometric analysis of the silver grains was 
measured under a magnification of 400 in 12 randomly selected fields per slide, using four normal tissues and four cancerous tissues. The number of grains were calculated as a percentage of the area occupied by the silver grains in a total area of each field.

Statistical analysis. Whenever indicated, data were analyzed by Student's $t$ test, using the StatView 512 computer program (Brainpoiwer, Inc., Calabasas, CA).

\section{Results}

In normal human pancreatic tissues, EGF receptor immunoreactivity was present on the apical surface of most ductal cells and on the surface and partially in the cytoplasm of many acinar cells (Fig. $1 A$ ). EGF (Fig. $1 B$ ) and TGF- $\alpha$ (Fig. 1, $C$ and $D$ ) immunoreactivity was present on the surface and in the cytoplasm of most ductal cells and many acinar cells. However, within the acini, TGF- $\alpha$ immunoreactivity was most prominent at the basal aspect of the cells (Fig. 1D).

In cancerous human pancreatic tissues, immunoreactivity for EGF receptor was present on the apical surface of all cancer cells with ductal structures within the invasive ductal adenocarcinomas (Fig. $2 A$ ). EGF (Fig. $2 C$ ) and TGF- $\alpha$ (Fig. $2 E$ ) immunoreactivity was diffusely positive on the surface and in the cytoplasm of these cells. Immunofluorescent staining of the adenocarcinomas revealed diffuse cellular distribution of EGF receptor (Fig. $2 B$ ), EGF (Fig. $2 D$ ), and TGF- $\alpha$ (Fig. $2 F$ ) in all duct-shaped cancer cells, which was especially intense at the apical surfaces in the case of the EGF receptor and TGF- $\alpha$, and in the supranuclear region in the case of EGF.

Immunoblotting with the respective antibodies also revealed a marked increase in EGF receptor, EGF, and TGF- $\alpha$ levels in the cancerous tissues (Fig. 3). Densitometric analysis of the autoradiographs indicated that EGF receptor and TGF- $\alpha$ protein levels were increased in the cancerous tissues by $10.6 \pm 4.5(P<0.05)$ and $13.8 \pm 4.9(P<0.02)$, respectively, by comparison with the normal tissues (fold increase, mean $\pm S E$ ). In the case of EGF, the protein levels were below the level of detection in the normal human pancreas, but were readily evident in the cancerous tissues (Fig. 3).

Northern blot analysis of total RNA demonstrated the presence of low levels of mRNA encoding the EGF receptor (Fig. 4) and EGF (Fig. 5), and relatively high levels of TGF- $\alpha$ mRNA (Fig. 5) in the normal human pancreas. In contrast, in the ductal adenocarcinomas, there was a marked increase in all three mRNA moieties. Densitometric analysis of the Northern blots indicated that, by comparison with the normal pancreas, there was a 3-, 15-, and 10-fold increase in the mRNA levels encoding the EGF receptor, EGF, and TGF- $\alpha$, respectively (Fig. 6). However, there did not appear to be any correlation between the histological grade of the pancreatic tumors and the levels of expression of the EGF receptor, EGF, and TGF- $\alpha$.

In situ hybridizations with antisense probes revealed that the mRNAs encoding the EGF receptor and EGF were ex-
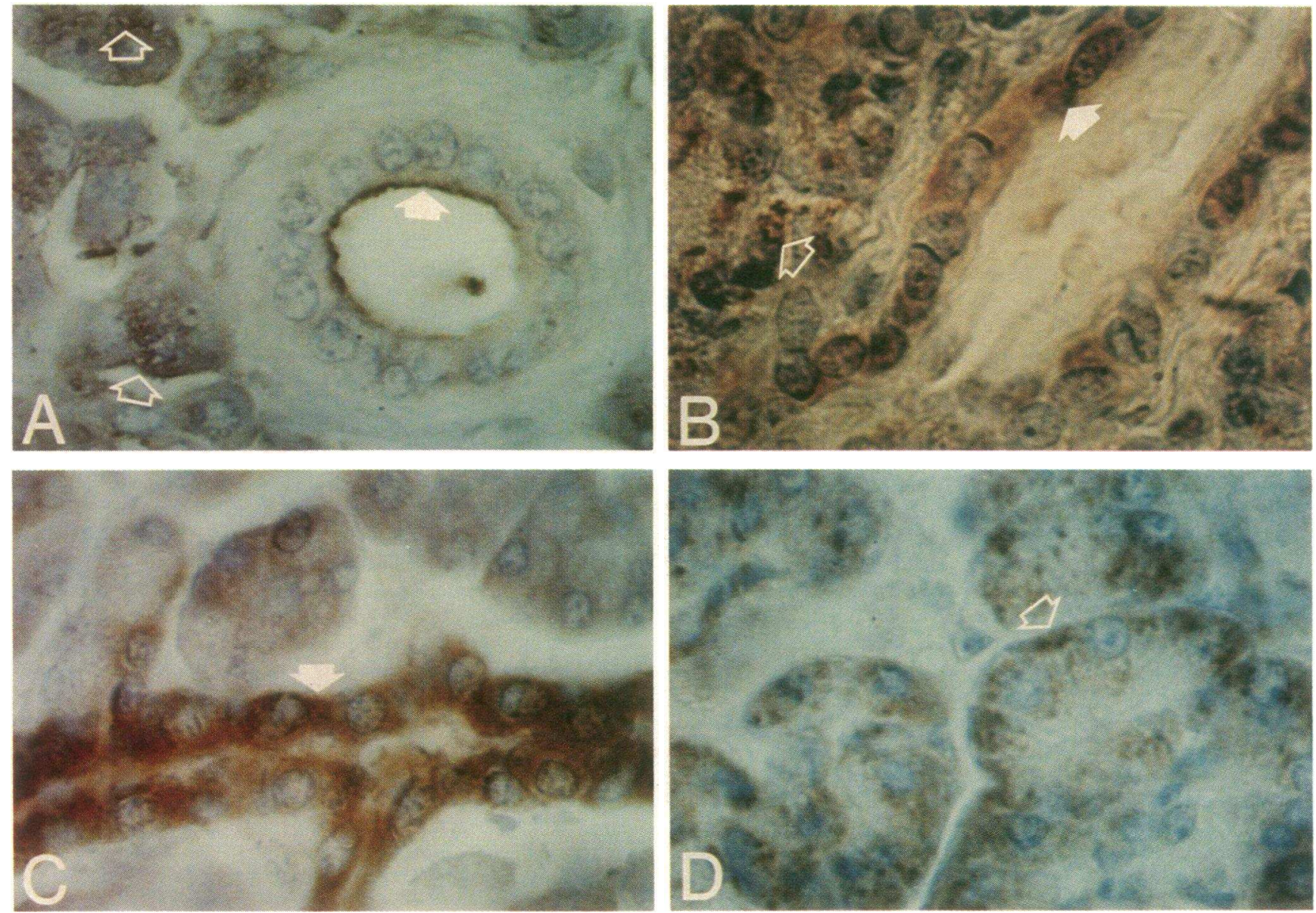

Figure 1. EGF receptor, EGF, and TGF- $\alpha$ in the normal human pancreas. Proteins were detected by immunohistochemistry. Immunostaining of the EGF receptor $(A)$, EGF $(B)$, and TGF- $\alpha(C$ and $D)$ is seen in ductal cells (white arrows) and acinar cells (open arrows). Magnification, 400. 

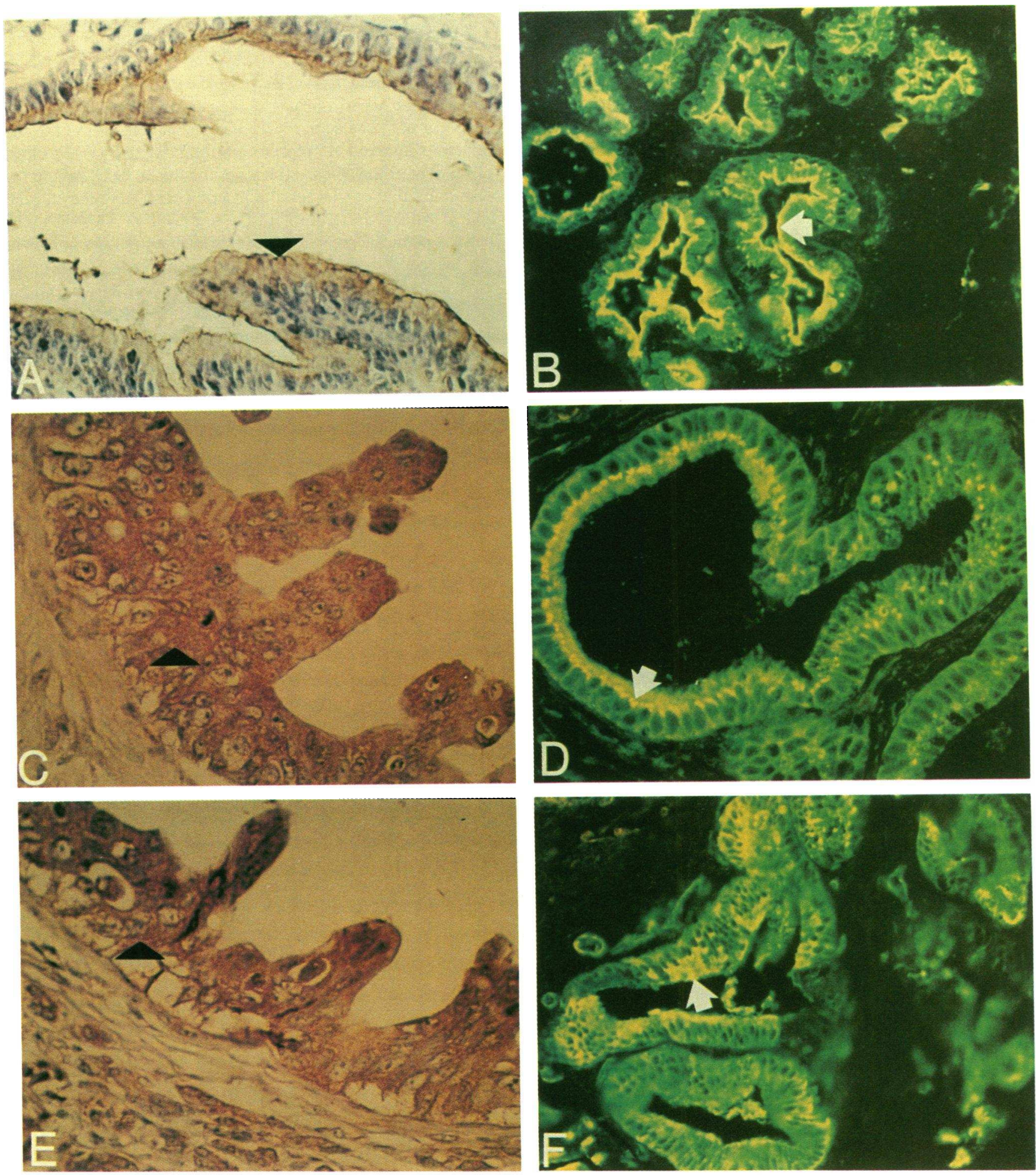

Figure 2. EGF receptor, EGF, and TGF- $\alpha$ in human ductal pancreatic adenocarcinomas. Proteins were detected by immunohistochemistry and indirect immunofluorescence. Immunostaining reveals apical localization of the EGF receptor $(A)$, and diffuse distribution of EGF $(C)$, and TGF- $\alpha(E)$ in the cytoplasm of ductal-shaped carcinoma cells (arrowheads). Immunofluorescence reveals areas of increased apical staining for the EGF receptor $(B)$ and TGF- $\alpha(F)$, and increased supranuclear distribution for EGF $(D)$, as indicated by the white arrows. Magnification: $A, B, D$, and $F, 100 ; C$ and $E, 200$.

pressed at low levels in the acinar cells (Fig. 7) and ductal cells (Fig. 8) of the normal human pancreas, but that the TGF- $\alpha$ mRNA was expressed at high levels in both cell types (Figs. 7 and 8). All three mRNA moieties tended to localize at the basal portion of the acinar cells (Fig. 7), and this basal distribution was especially prominent in the case of TGF- $\alpha$ (Fig. $7 E$ ). In the ductal structures of the normal pancreas, all three mRNA moieties tended to localize at the apical portion of cells (Fig. 


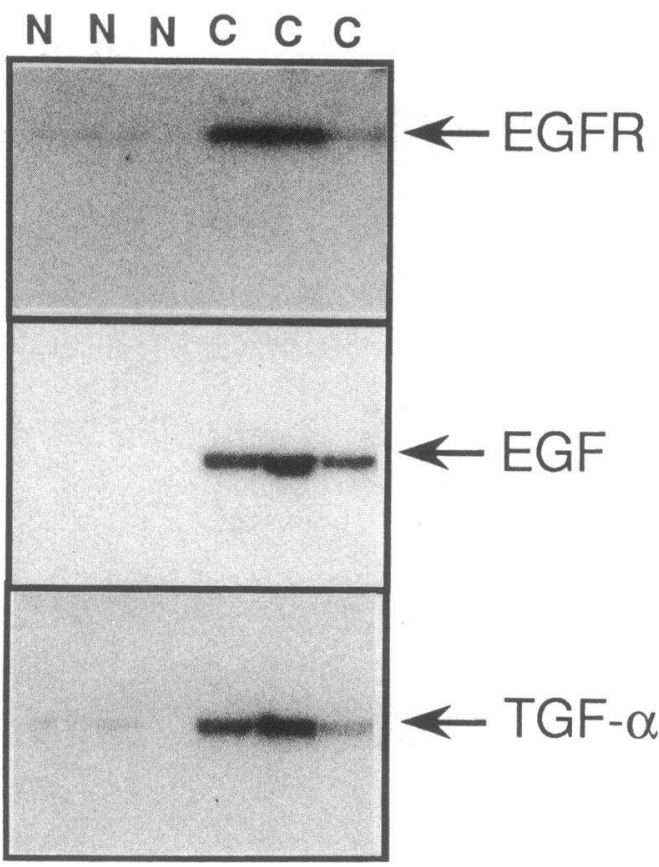

Figure 3. Immunobloting. Homogenates prepared from three normal $(N)$ and three cancerous $(C)$ pancreatic tissue samples were subjected to immunobloting using monoclonal antibodies that are specific for the indicated proteins, followed by incubations with goat anti-mouse IgG and ${ }^{125} \mathrm{I}$-protein $\mathrm{A}$, as described in Methods. Each lane represents $0.1 \mathrm{mg}$ of protein. Autoradiograph exposure times were $72 \mathrm{~h}$ for EGF receptor $(E G F R)$, and $48 \mathrm{~h}$ for EGF and TGF- $\alpha$.

8). In the invasive ductal adenocarcinomas, there was a marked and diffuse increase in the levels of all three RNA species by comparison with the normal pancreas (Fig. 7, Table I). EGF receptor mRNA signal was also consistently detected in the endothelial cells of blood vessels in both the normal and cancerous (Fig. 7) pancreas.

\section{Discussion}

The EGF receptor is an important protein whose activation initiates a cascade of biological processes in numerous cell types (28). Previous studies have suggested that the EGF receptor may participate in the regulation of pancreatic exocrine function. Thus, the pancreatic acinar cell has specific, high affinity EGF receptors (29), and EGF is present in the pancreatic juice in humans (30). EGF potentiates secretagogue-activated digestive enzyme release in cultured mouse pancreatic acini (31), prevents caerulein-induced desensitization of acinar cell secretory responsiveness when injected subcutaneously in rats (32), interacts with both stimulatory (Gs) and inhibitory (Gi) GTP binding proteins (33), and alters cholecystokinin-induced activation of chloride conductance in the pancreatic acinar cell (34). EGF also enhances the survival of rat pancreatic acinar cells in serum-free culture (35), and either inhibits $(1 \mathrm{nM})$ or enhances $(10 \mathrm{nM})$ the proliferation of mouse pancreatic acini grown on a collagen gel $(36,37)$. In vivo, EGF decreases thymidine incorporation into pancreatic DNA in male Sprague-Dawley rats (32), but enhances thymidine incorporation in male Wistar rats (38). Taken together, these studies suggest that the EGF receptor may have an important role in maintaining acinar cell integrity and differentiated function, and that its effects on pancreatic cell proliferation may be species specific.

In the present study, we have determined that the EGF receptor and its two principal ligands, EGF and TGF- $\alpha$, are found in both the acinar cells and ductal cells of the normal human pancreas. EGF receptor immunoreactivity is especially prominent at the apical surfaces of the ductal cells, raising the possibility that at this site the receptor may function to bind and internalize intraluminal EGF and TGF- $\alpha$. This may partially explain the greater abundance of both growth factors in the duct cells by comparison with the acinar cells. However, all three proteins colocalize with their respective mRNAs, and the in situ hybridization data suggest that the mRNAs for both ligands are expressed to a greater extent in ductal cells than in acinar cells. Similarly, the abundance of TGF- $\alpha$ in the basal aspect of the acinar cells correlates with the increased expression of TGF- $\alpha$ at this site. Taken together, these observations suggest that all three proteins are synthesized in both acinar cells and duct cells.

The reasons for the coexpression in the normal pancreas of two growth factors that bind and activate the same receptor are not readily evident. It is possible that the two factors may regulate different biological functions in these cells. In support of this hypothesis, in $\mathrm{T}_{3} \mathrm{M}_{4}$ human pancreatic cancer cells, EGF and TGF- $\alpha$ exert differential effects on EGF receptor downregulation and tyrosine phosphorylation, and exhibit quantitative and qualitative differences with respect to the generation of biologically active inositol tris phosphate (39). It is also possible that the precursors to the two growth factors yield different peptides that have unknown regulatory functions in the exocrine pancreas. Irrespective of the reason, this coexpression suggests that both EGF and TGF- $\alpha$ may participate in the regu-

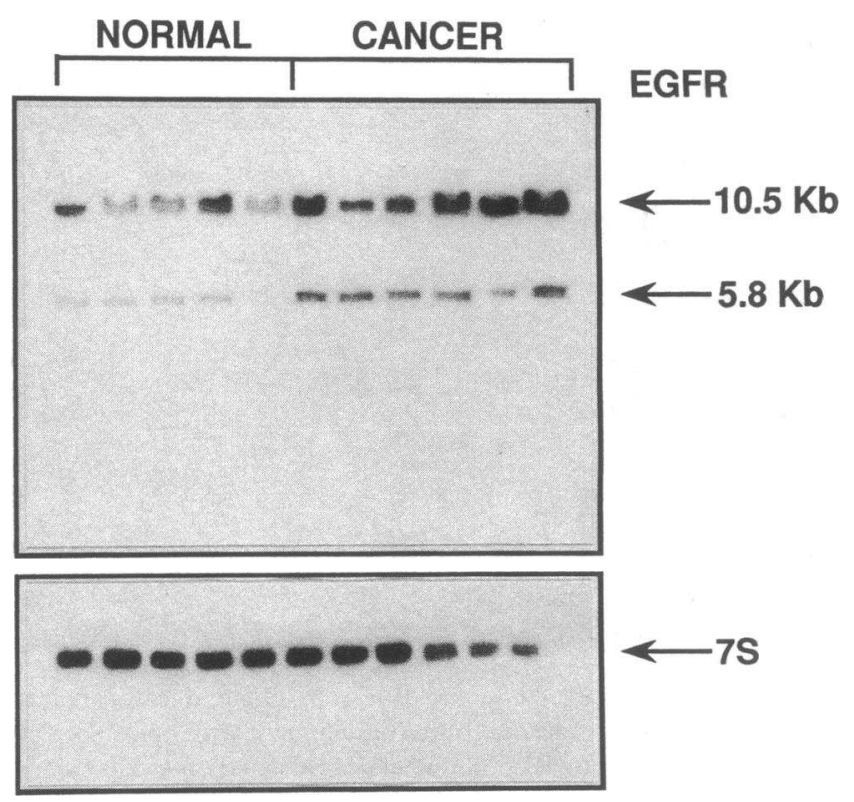

Figure 4. Analysis of EGF receptor mRNA levels in tissues. Total pancreatic RNA from normal and cancerous human pancreatic tissues was prepared by a guanidine thiocyanate extraction procedure and trans-blotted to a nylon membrane. The filter was probed with ${ }^{32}$ P-labeled EGF receptor riboprobe $\left(4 \times 10^{5} \mathrm{cpm} / \mathrm{ml}\right.$; 8-d exposure) and $7 \mathrm{~S} \mathrm{cDNA}\left(5 \times 10^{4} \mathrm{cpm} / \mathrm{ml} ; 18 \mathrm{~h}\right.$ exposure $)$. The EGF receptor (EGFR) mRNA migrates as two bands (10.5 and $5.8 \mathrm{~kb})$. The ribosomal 7S mRNA migrates as a $0.4-\mathrm{kb}$ species. 


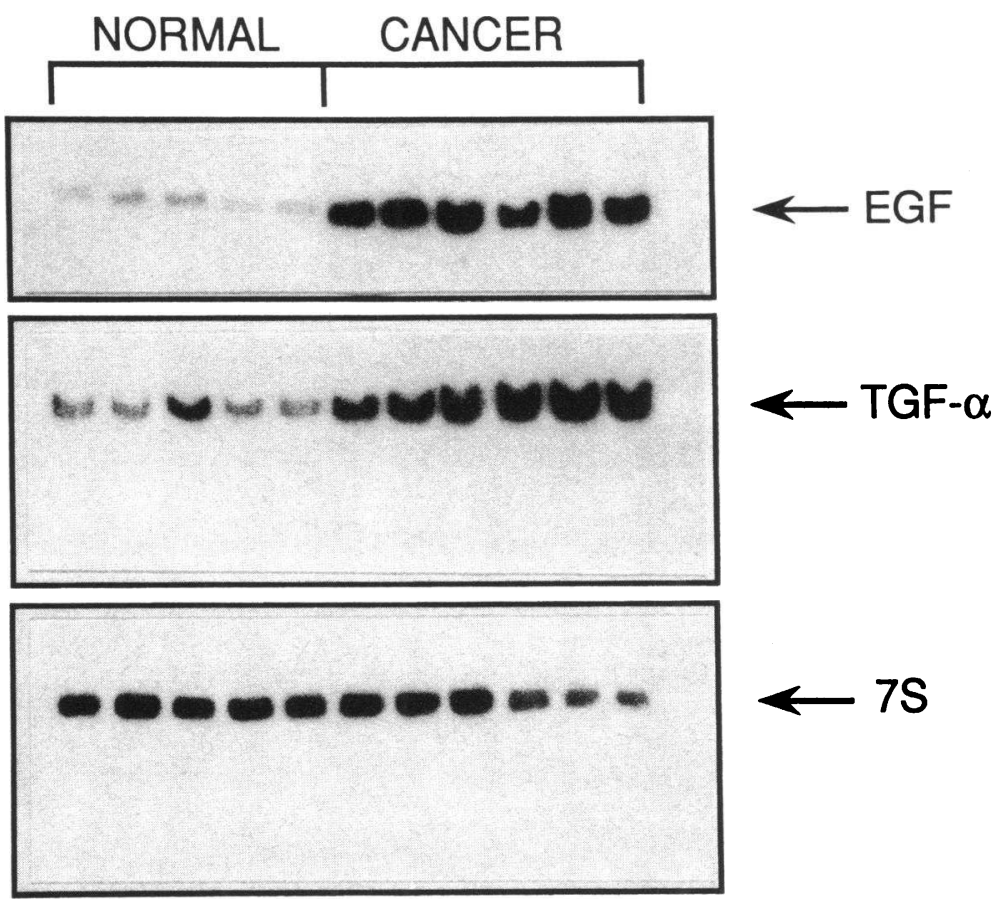

Figure 5. Analysis of growth factor mRNA levels in tissues. Pancreatic RNA was prepared as described in the legend to Fig. 2. The filter was probed with the ${ }^{32} \mathrm{P}$-labeled EGF cDNA $\left(2 \times 10^{5} \mathrm{cpm} / \mathrm{ml}\right.$; 4-d exposure $)$, TGF- $\alpha$ riboprobe $\left(2 \times 10^{5} \mathrm{cpm} / \mathrm{ml} ; 2-\mathrm{d}\right.$ exposure $)$, and $7 \mathrm{~S}$ cDNA $\left(5 \times 10^{4} \mathrm{cpm} / \mathrm{ml} ; 18-\mathrm{h}\right.$ exposure $)$.

lation of acinar and duct cell function, and raises the possibility that this regulation is mediated, in part, through autocrine and paracrine activation of the EGF receptor. Furthermore, the presence of EGF receptors in the pancreatic endothelial cells suggests that circulating EGF and TGF- $\alpha$ may also contribute to this regulation.

Previous studies have demonstrated that cultured human pancreatic cancer cells overexpress the EGF receptor and produce TGF- $\alpha(8,9)$. In addition, immunohistochemical studies have indicated that there are increased levels of EGF receptors and TGF- $\alpha$ in human pancreatic tumors $(40,41)$. Our present

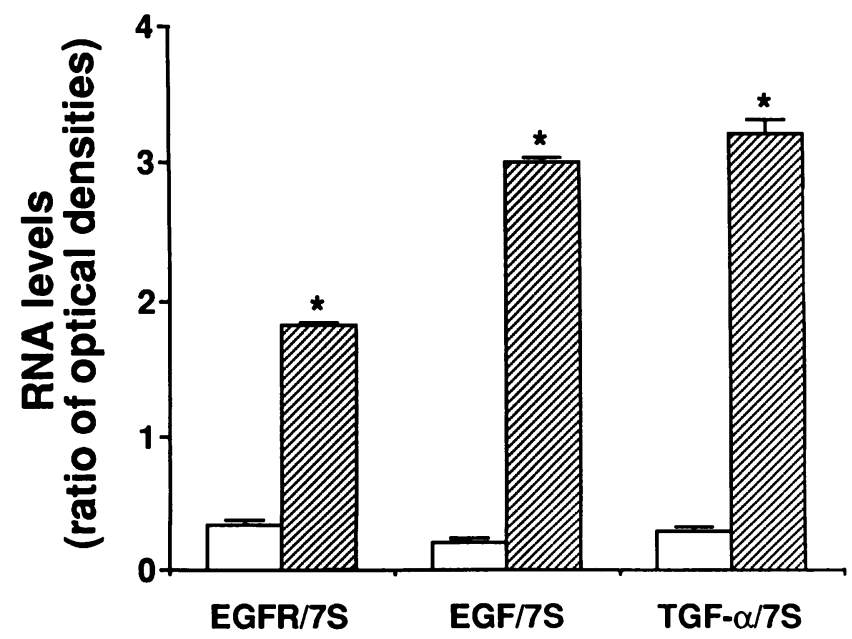

Figure 6. Densitometric analysis. The autoradiographs in Figs. 2 and 3 were analyzed by densitometry. Values are the means \pm SE from 20 normal human pancreatic samples and 22 human ductal carcinoma samples. EGFR/7S: ratio of EGF receptor to 7S signal. EGF/7S: ratio of EGF to 7S signal. TGF- $\alpha / 7 \mathrm{~S}$ : ratio of TGF- $\alpha$ to /7S signal. ${ }^{*} P<0.0001$ when compared with control. $\square$, Normal; $:$, cancer. findings indicate that the EGF receptor, EGF, and TGF- $\alpha$ are all expressed at higher levels in human pancreatic cancer by comparison with the normal human pancreas, and that this overexpression is especially marked in the ductal-shaped cells of the invasive adenocarcinoma. In these cells, EGF receptor and TGF- $\alpha$ immunoreactivity is found on both the cell surface and in the cytoplasm, and is especially prominent at the apical surfaces. In contrast, EGF exhibits a diffuse cytoplasmic pattern with increased immunostaining in the supranuclear region of the cells. The increased immunostaining is associated with elevated protein levels by immunoblotting and with an increase in the respective mRNA levels. These observations point toward either enhanced production and/or decreased degradation of these mRNA moieties in the tumor cells. The colocalization of these mRNAs indicates that the three proteins are synthesized within the same cells, thereby supporting the concept of a functional EGF receptor autocrine cycle in human pancreatic cancer cells. With respect to TGF- $\alpha$, this hypothesis is strengthened by the known ability of the membrane-bound TGF- $\alpha$ precursor to activate the EGF receptor (42), and by the abundance of EGF receptors and TGF- $\alpha$ at the apical surfaces of duct cells.

Table I. Quantitative Analysis of In Situ Hybridization Data

\begin{tabular}{lcll}
\hline & EGF receptor & \multicolumn{1}{c}{ EGF } & \multicolumn{1}{c}{ TGF- $\alpha$} \\
\hline Normal & $1.32 \pm 0.18$ & $1.55 \pm 0.49$ & $11.43 \pm 2.13$ \\
Cancer & $22.60 \pm 1.39^{*}$ & $25.6 \pm 1.04^{*}$ & $48.50 \pm 3.06^{*}$
\end{tabular}

Data shown in Fig. 6 were analyzed by quantitative videoimage analysis as described in Methods. Values are means \pm SE from four normal and four cancerous tissues. The number of grains were calculated as a percentage of the area occupied by the silver grains in a total area of each field. $* P<0.0005$ when compared with corresponding values in normal pancreatic tissue. 

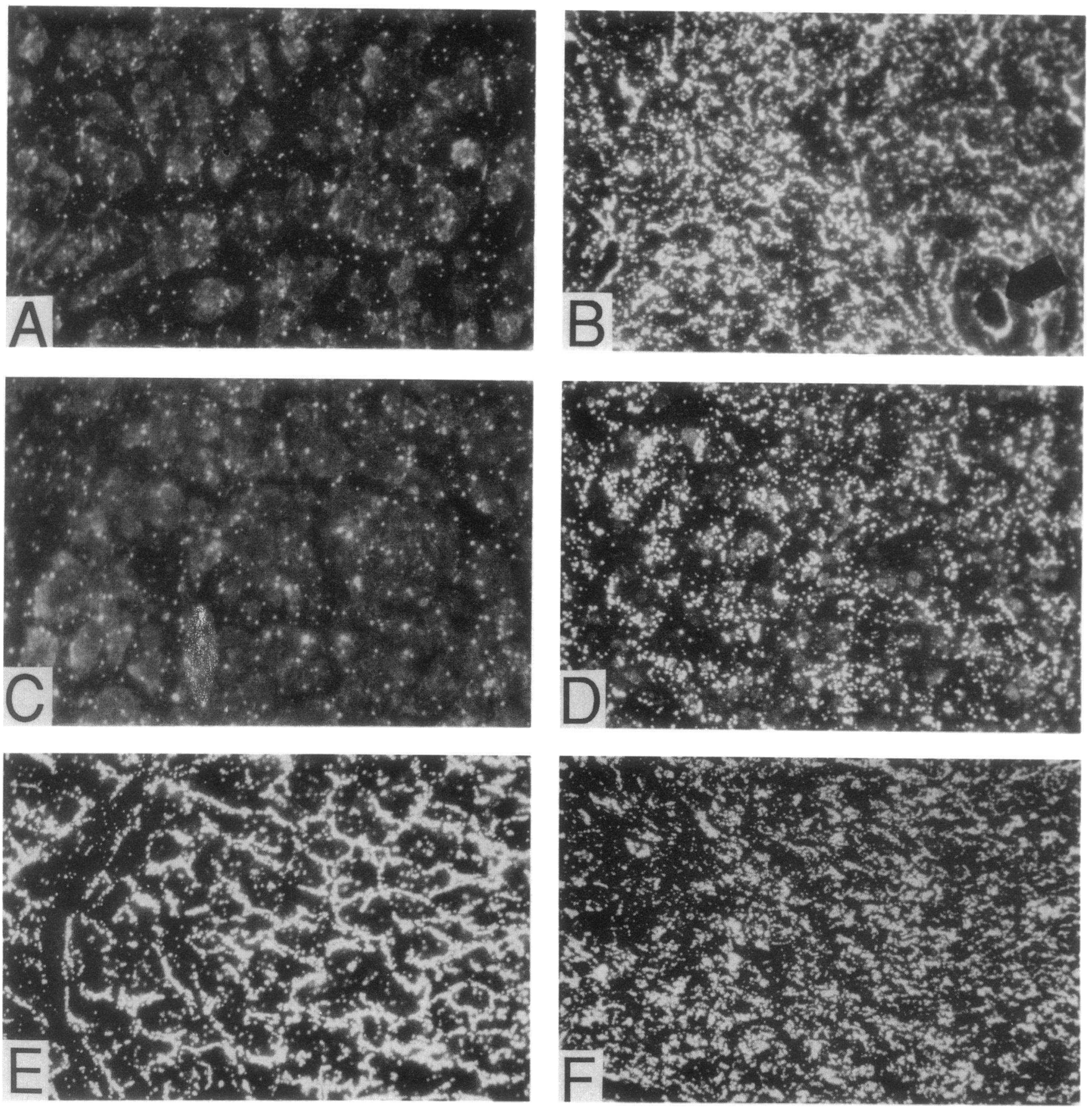

Figure 7. In situ hybridization analyzed by dark-field microscopy. Detection of EGF receptor $(A$ and $B)$, EGF $(C$ and $D)$, and TGF- $\alpha(E$ and $F)$ mRNA with antisense probes in normal $(A, C$, and $E)$ and pancreatic ductal adenocarcinomas $(B, D$, and $F)$ by in situ hybridization. Arrow $(B)$ points to EGF receptor signal in endothelial cells. Magnification, 100.

It is widely recognized that perturbations in the functions of growth factors and their receptors and/or their aberrant expression may lead to abnormal cell growth, acquisition of features that are characteristic of the transformed phenotype, and progression to neoplasia with unrestrained growth and ability to invade normal tissues and metastasize (43). Increased EGF receptor number is associated with enhanced metastatic potential in human breast cancer (13) and enhanced tumor invasiveness in human bladder cancer (14). Furthermore, the EGF receptor is overexpressed in several different types of malignancies in humans, including glial, pulmonary, breast, gastric, squamous, and colonic carcinomas (9). A variety of cancers also exhibit enhanced expression of TGF- $\alpha$ (44). Recently, a number of human gastric carcinomas were shown to express high mRNA levels encoding the EGF receptor, EGF, and TGF- $\alpha$ (45). However, to our knowledge, our findings are the first to document by in situ hybridization that a given malignancy can be associated with overexpression of the EGF receptor, EGF, and TGF- $\alpha$ by the same cells within the tumor mass.

Three lines of evidence suggest that TGF- $\alpha$ may have an especially important role in the pathophysiology of pancreatic neoplasms. TGF- $\alpha$ is more potent than EGF at stimulating the 

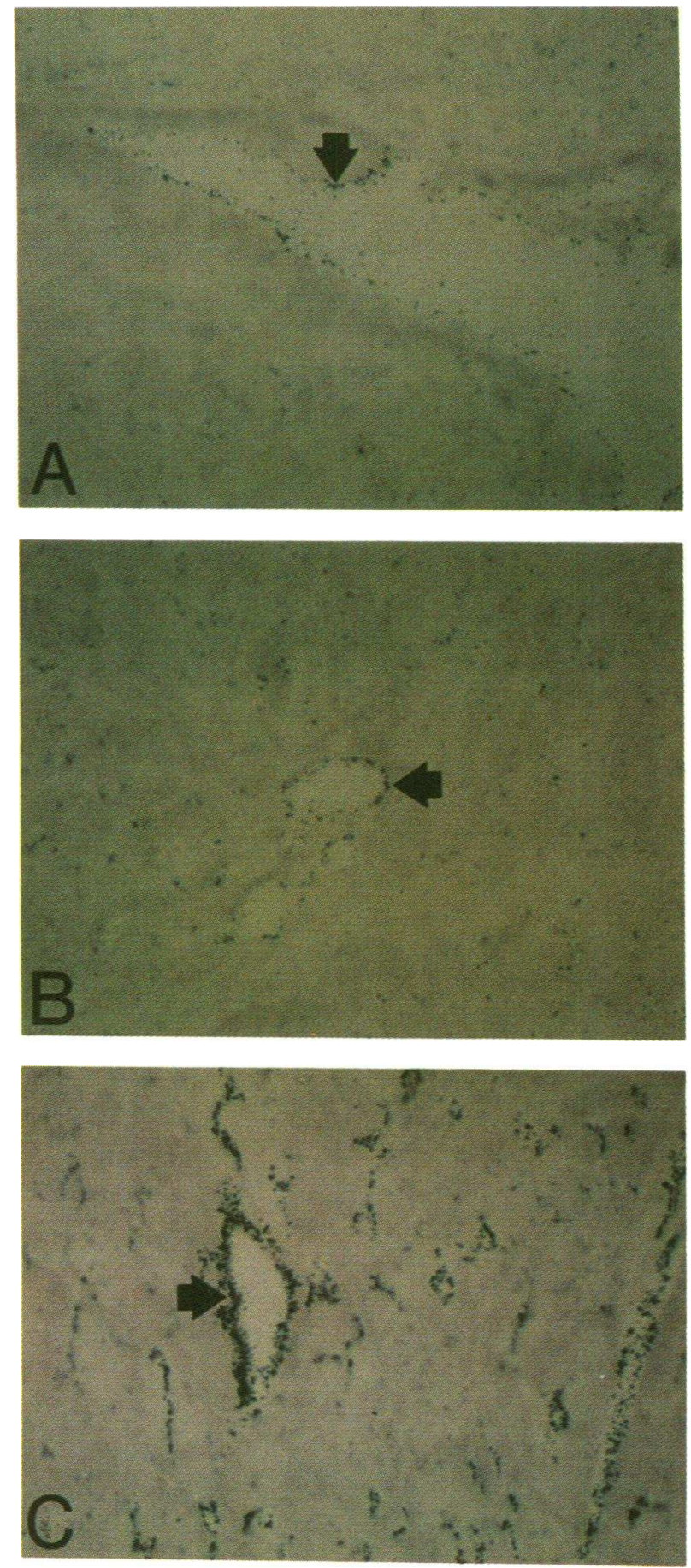

Figure 8 . In situ hybridization analyzed by light-field microscopy. Expression pattern of mRNAs encoding EGF receptor $(A)$, EGF $(B)$, and TGF- $\alpha(C)$ in the normal human pancreas, as detected with antisense probes. The mRNAs encoding EGF receptor, EGF, and TGF$\alpha$ are found at high levels at the apical portion of the pancreatic ductal cells (arrows). Magnification, 200.

anchorage-independent growth of cultured human pancreatic cancer cells (9). TGF- $\alpha$ binding, but not EGF binding, is increased at $\mathrm{pH} 8.2$ (39), which is the $\mathrm{pH}$ of human pancreatic juice. The exocrine pancreas is one of the principal target organs that is damaged in transgenes that overexpress TGF- $\alpha$ $(46,47)$. These transgenes exhibit an increase in pancreatic acinar cell and fibroblastic proliferation, in association with extensive pseudoductular metaplasia $(46,47)$. Taken together, these observations raise the possibility that, within the ductular microenvironment of the exocrine pancreas, the alkaline $\mathrm{pH}$ and the abundance of EGF, TGF- $\alpha$, and EGF receptors may provide pancreatic cancer cells with a distinct growth advantage that contributes to the clinical aggressiveness of this malignancy.

\section{Acknowledgments}

This study was supported by Public Health Service Grant CA-40162 awarded by the National Cancer Institute to M. Korc. The authors thank Drs. M. Kobrin and A. Tarnowski for many helpful discussions during the course of this work.

\section{References}

1. Beazley, R. M., and I. Cohn, Jr. 1981. Update on pancreatic cancer. CaCancer J. Clin. 38:310-319.

2. Cancer Incidence and Mortality in the United States, SEER 1973-1976. 1978. U. S. Dept. of Health, Education, and Welfare, Bethesda, MD, NIH Publication No. 78-1837.

3. Levine, G., W. H. Remine, R. E. Hermann, P. S. Schein, and I. Cohn. 1978. Cancer of the pancreas. Am. J. Surg. 135:185-191.

4. Korc, M., P. Meltzer, and J. Trent. 1986. Enhanced expression of epidermal growth factor receptor correlates with alterations of chromosome 7 in human pancreatic cancer. Proc. Natl. Acad. Sci. USA. 83:5141-5144.

5. Smith, J. J., R. Derynck, and M. Korc. 1987. Production of transforming growth factor $\alpha$ in human pancreatic cancer cells: evidence for a superagonist autocrine cycle. Proc. Natl. Acad. Sci. USA. 84:7567-7570.

6. Korc, M., and J. E. Finman. 1989. Attenuated processing of epidermal growth factor in the face of marked degradation of transforming growth factor- $\alpha$. J. Biol. Chem. 264:14990-14999.

7. Libermann, T. A., N. Razon, A. D. Bartal, Y. Yarden, J. Schlessinger, and H. Soreq. 1984. Expression of epidermal growth factor receptors in human brain tumors. Cancer Res. 44:753-760.

8. Ro, J., S. M. North, G. E. Gallick, G. N. Hortobagyi, J. U. Gutterman, and M. Blick. 1987. Amplified and overexpressed epidermal growth factor receptor gene in uncultured primary human breast carcinoma. Cancer Res. 48:161-164.

9. Sainsbury, J. R. C., G. V. Sherbet, J. R. Farndon, and A. L. Harris. 1985. Epidermal-growth-factor receptors in human brain tumors. Lancet. i:364-366.

10. Neal, D. E., M. K. Bennett, R. R. Hall, C. Marsch, P. D. Abel, J. R. C. Sainsbury, and A. L. Harris. 1985. Epidermal-growth-factor receptors in human bladder cancer: comparison of invasive and superficial tumors. Lancet. i:366368 .

11. Watanabe, S., E. Lazar, and M. B. Sporn. 1987. Transformation of normal rat kidney (NRK) cells by an infectious retrovirus carrying a synthetic rat type $\alpha$ transforming growth factor gene. Proc. Natl. Acad. Sci. USA. 84:1258-1262.

12. Heidaran, M. A., T. P. Fleming, D. P. Bottaro, G. I. Bell, P. P. Di Fiore and S. A. Aaronson. 1990. Transformation of NIH3T3 fibroblasts by an expression vector for the human epidermal growth factor precursor. Oncogene. 5:12651270.

13. Kawamoto, T., J. D. Sato, A. Le, J. Polikoff, S. H. Sato, and J. Mendelsohn. 1983. Growth stimulation of A431 cells by EGF: identification of high affinity receptors for epidermal growth factor by an anti-receptor monoclonal antibody. Proc. Natl. Acad. Sci. USA. 80:1337-1341.

14. Arteaga, C. L., M. D. Johnson, G. Todderud, R. F. Coffey, G. Carpenter, and D. L. Page. 1991. Elevated content of the tyrosine kinase substrate phospholipase C- $\gamma 1$ in primary human breast carcinomas. Proc. Natl. Acad. Sci. USA 88:10435-10439.

15. Laemmli, U. K. 1970. Cleavage of structural proteins during the assembly of the head of bacteriophage T4. Nature (Lond.). 227:680-685.

16. Schagger, H., and G. von Jagow. 1987. Tricine-sodium dodecyl sulphatepolyacrylamide gel electrophoresis for the separation of proteins in the range from 1 to $100 \mathrm{kDa}$. Anal. Biochem. 166:368-379.

17. Towbin, H., T. Staehelin, and J. Gordon. 1979. Electrophoretic transfer of proteins from polyacrylamide gels to nitrocellulose sheets: procedure and some applications. Proc. Natl. Acad. Sci. USA. 76:4350-4354.

18. Glinsmann-Gibson, B. J., and M. Korc. 1991. Regulation of transforming growth factor- $\alpha$ mRNA expression in $\mathrm{T}_{3} \mathrm{M}_{4}$ human pancreatic carcinoma cells. Pancreas. 6:142-149.

19. Chang, S., P. M. Brannon, and M. Korc. 1990. Effects of dietary manganese deficiency on rat pancreatic amylase mRNA levels. J. Nutr. 120:1228-1234.

20. Korc, M., D. Owerbach, C. Quinto, and W. J. Rutter. 1981. Pancreatic islet-acinar cell interaction: amylase messenger RNA levels are determined by insulin. Science (Wash. DC). 213:351-353. 
21. Balmain, A., R. Krumlauf, J. K. Vass, and G. D. Birnie. 1982. Cloning and characterization of the abundant cytoplasmic 7S RNA from mouse cells. Nucleic Acids Res. 10:4259-4277.

22. Sambrook, J., E. F. Fritsch, and T. Maniatis. 1989. Molecular Cloning: A Laboratory Manual. Cold Spring Harbor Laboratory Press, Cold Spring Harbor, NY. 545 pp.

23. Feinberg, A. P., and B. Vogelstein. 1983. A technique for radiolabelling DNA restriction endonuclease fragments to high specific activity. Anal. Biochem. 132:6-13.

24. Melton, D. A., P. A. Kreig, M. R. Rebagliata, T. Mainiatis, K. Zinn, and M. R. Green. 1984. Efficient in vitro synthesis of biologically active RNA and RNA hybridization probes from plasmids containing a bacteriophage SP6 promoter. Nucleic Acids Res. 12:7035-7056.

25. Wilcox, J. N., K. M. Smith, L. T. Williams, S. M. Schaluartz, and D. Gordon. 1988. Platelet-derived growth factor $m R$ NA detection in human atherosclerotic plaques by in situ hybridization. J. Clin. Invest. 82:1134-1143.

26. Murray, J. C., C. R. DeHaven, and G. I. Bell. 1986. RFLPs for epidermal growth factor (EGF), a single copy sequence at 4q25-4q27. Nuclic Acids Res. 14:5117.

27. Tarnawski, A. S., I. J. Sarfeh, A. Hajduczek, H. X. Bui, W. Dabros, and H. Gergely. 1988. Microvascular abnormalities of the portal hypertensive gastric mucosa. Hepatology. 8:1488-1494.

28. Yarden, Y., and A. Ullrich. 1988. Molecular analysis of signal transduction by growth factors. Biochemistry. 27:3113-3119.

29. Korc, M., L. M. Matrisian, S. R. Planck, and B. M. Magun. 1983. Binding of epidermal growth factor in rat pancreatic acini. Biochem. Biophys. Res. Commun. 111:1066-1073.

30. Hirata, Y., M. Uchikashi, M. Nakajima, and S. Matsukura. 1982. Immunoreactive human epidermal growth factor in human pancreatic juice. J. Clin. Endocrinol. \& Metab. 54:1242-1245.

31. Logsdon, C. D., and J. A. Williams. 1983. Epidermal growth factor binding and biologic effects on mouse pancreatic acini. Gastroenterology. 85:339345 .

32. Morisset, J., L. Larose, and M. Korc. 1989. Epidermal growth factor inhibits rat pancreatic cell proliferation, causes acinar cell hypertrophy, and prevents caerulein-induced desensitization of amylase release. Endocrinology. 124:2693-2698.

33. Profrock, A., S. Schnefel, and I. Schulz. 1991. Receptors for insulin interact with Gi-proteins and for epidermal growth factor with $\mathrm{Gi}$ - and $\mathrm{Gs}$-proteins in rat pancreatic acinar cells. Biochem. Biophys. Res. Commun. 175:380-386.

34. Piiper, A., A. Profrock, and I. Schulz. 1991. Effects of epidermal growth factor and calcium omission on cholecystokinin-stimulated Cl-conductance in rat pancreatic zymogen granules. Biochem. Biophys. Res. Commun. 181:827832.
35. Brannon, P. M., B. M. Orrison, and N. Kretchmer. 1985. Primary cultures of rat pancreatic acinar cells in serum-free medium. In Vitro Cell. \& Dev. Biol. 21:6-14.

36. Logsdon, C. D., and J. A. Williams. 1986. Pancreatic acinar cells in monolayer culture: direct trophic effects of caerulein in vitro. Am. J. Physiol. 250:G440-447.

37. Logsdon, C. D. 1986. Stimulation of pancreatic acinar cell growth by CCK, epidermal growth factor, and insulin in vitro. Am. J. Physiol. 251:G487G494:

38. Dembinsky, A., H. Gregory, S. J. Konturek, and M. Polanski. 1982. Trophic action of epidermal growth factor on the pancreas and gastroduodenal mucosa in rats. J. Physiol. 325:35-42.

39. Korc, M., B. Chandrasekar, and G. N. Shah. 1991. Differential binding and biological activities of epidermal growth factor and transforming growth factor $\alpha$ in a human pancreatic cancer cell line. Cancer Res. 51:6243-6249.

40. Yamanaka, Y., M. Onda, E. Uchida, T. Kobayashi, K. Sasajima, A. Tokunaga, T. Tajiri, K. Egami, and G. Asano. 1990. Immunohistochemical study on epidermal growth factor and its receptor in human pancreatic carcinoma. Jpn. J. Gastroenterol. 87:1544-1550.

41. Barton, C. M., P. A. Hall, C. M. Hughes, W. J. Gullick, and N. R. Lemoine. 1991. Transforming growth factor alpha and epidermal growth factor in human pancreatic cancer. J. Pathol. 163:111-116.

42. Brachmann, R., P. B. Lindquist, M. Nagashima, W. Kohr, T. Lipari, M. Napier, and R. Derynck. 1989. Transmembrane TGF- $\alpha$ precursors activate EGF/TGF- $\alpha$ receptors. Cell. 56:691-700.

43. Aaronson, S. A. 1991. Growth factors and cancer. Science (Wash. DC). 254:1146-1153.

44. Derynck, R., D. V. Goeddel, A. Ullich, J. U. Gutterman, R. D. Williams, T. S. Bringman, and W. H. Berger. 1987. Synthesis of messenger RNAs for transforming growth factor $\alpha$ and $\beta$ and the epidermal growth factor receptor by human tumors. Cancer Res. 47:707-712.

45. Yoshida, K., E. Kyo, T. Tsujino, T. Sano, M. Niimoto, and E. Tahara. 1990. Expression of epidermal growth factor, transforming growth factor- $\alpha$ and their receptor genes in human gastric carcinomas; implication for autocrine growth. Jpn. J. Cancer Res. 81:43-51.

46. Sandgren, E. P., N. C. Luetteke, R. D. Palmiter, R. L. Brinster, and D. C. Lee. 1990. Overexpression of TGF- $\alpha$ in transgenic mice: induction of epithelial hyperplasia, pancreatic metaplasia, and carcinoma of the breast. Cell. 61:11211135

47. Jhappan, C., C. Stahle, R. N. Harkins, N. Fausto, G. H. Smith, and G. T. Merlino. 1990. TGF- $\alpha$ overexpression in transgenic mice induces liver neoplasia and abnormal development of the mammary gland and pancreas. Cell. 61:11371146. 